\title{
Status of renewable energy in Cameroon
}

\author{
Dieudonné Kaoga Kidmo ${ }^{1,}$, Kodji Deli ${ }^{1}$, and Bachirou Bogno ${ }^{2}$ \\ ${ }^{1}$ Department of Renewable Energy, National Advanced School of Engineering of Maroua, University of Maroua, P.O. Box 46 \\ Maroua, Cameroon \\ ${ }^{2}$ Department of Physics, Higher Teachers' Training College, University of Maroua, P.O. Box 46 Maroua, Cameroon
}

Received: 20 December 2020 / Received in final form: 17 January 2021 / Accepted: 17 January 2021

\begin{abstract}
Globally, the continuous increase of energy consumption coupled with the depletion of the limited fossil fuel sources and their negative impacts on the environment, has shifted focus towards renewables for a sustainable development. For the last fifteen years, the world has enjoyed renewables generation capacity increases in a double-digit Terawatt-hours range. Although renewables consumption is fast developing in Asia Pacific, Europe and North America, significant coordination efforts are required among stakeholders in subSaharan Africans countries such as Cameroon. In 2018, the total final energy consumption in Cameroon was 7.41 Mtoe, $74.22 \%$ of which was from biomass, $18.48 \%$ from fossil fuels and $7.30 \%$ from electricity. Furthermore, $6977 \mathrm{GWh}$ of electricity was produced, $78.29 \%$ of which from the major electricity operator (ENEO S.A. Cameroon) and $21.71 \%$ from independent producers (GLOBELEQ, ALTAAQA Sinohydro China and AGGREKO). More than three quarter of electricity produced were consumed by industry $(57.04 \%)$ and residential (20.74\%) sectors. The country's installed electricity generation capacity rose to $1402 \mathrm{MW}, 56.15 \%$ of which was from hydropower, $43.84 \%$ from fossil fuels ( $17.55 \%$ from natural gas and $26.29 \%$ from oil) and $0.01 \%$ from solar photovoltaic. The promotion of renewable energy is an important part of Cameroon's plan to increase energy security and provide job opportunities to the country. Yet, the lack of proactive and long-term renewable energy policy and laws, in addition to less attention paid to renewable energy training and research, financing mechanisms, and unaffordable costs of renewable energy technologies to the poor population are amongst present issues hindering the development of renewable energy in the country. Hence, this paper aims to highlight the present status of renewable energy exploitation and development in Cameroon.
\end{abstract}

\section{Introduction}

For decades, the world has witnessed a sustained increase in energy demand added to faster depletion of coal, natural gas, and crude oil reserves as well as cumulative negative impacts of fossil fuels to the environment. In 2018, the share of world primary energy consumption by source was oil at $34 \%$, coal at $27 \%$, natural gas at $24 \%$, hydro at $7 \%$, nuclear at $4 \%$ and renewables (solar, wind, geothermal, biomass, etc.) at $4 \%$. Driven by higher energy demand, the world's primary energy consumption rose $2.9 \%$ to reach 13,865 MTOE, $85 \%$ of which from fossil fuels, while global energyrelated $\mathrm{CO}_{2}$ emissions showed a growth rate of $1.95 \%$ to a historic high of 33891 MTOE [1].This energy crisis situation has driven the world towards renewable energy (RE) sources, which are immensely available and have the potential to efficiently satisfy an appropriate portion of the world energy needs, while minimizing environmental pollution and health hazards associated with the use of coal, natural gas, and crude oil [2].

\footnotetext{
* e-mail: kidmokaoga@gmail.com
}

In recent decades, the shift focus towards $\mathrm{RE}$ for a sustainable development has led to a double-digit growth rate increase in renewables consumption worldwide [3-5]. For the last fifteen years, renewables consumption worldwide showed annual growth rates ranging from $12.52 \%$ in 2005 to $19.30 \%$ in 2011 , and reached $2480 \mathrm{TWh}, 1.3 \%$ of which consumed in Africa [1]. Asia Pacific (40.2\%), Europe (30.7\%) and North America (21.2\%) represented the biggest renewables consumers. Despite a relative low share of renewables generation consumption, Africa has seen higher renewables consumption, mainly in the last seven years, with growth rates that ranged between $10 \%$ in 2012 and $56 \%$ in 2015 . The Africa renewables generation rose $19 \%$ to reach 32 TWh in 2018. South Africa was the biggest renewables' consumer (38.8\%), followed by Eastern Africa (27.1\%), Morocco (15.0\%) and Egypt (10.9\%) [5]. In the remaining subSaharan African countries such as Cameroon, renewables generation consumption is still low despite the huge and essentially untapped potential [6].

Therefore, the objective of this paper is to renew interest in RE and advocate for its development in the country. The originality of this paper lies in assessing main 


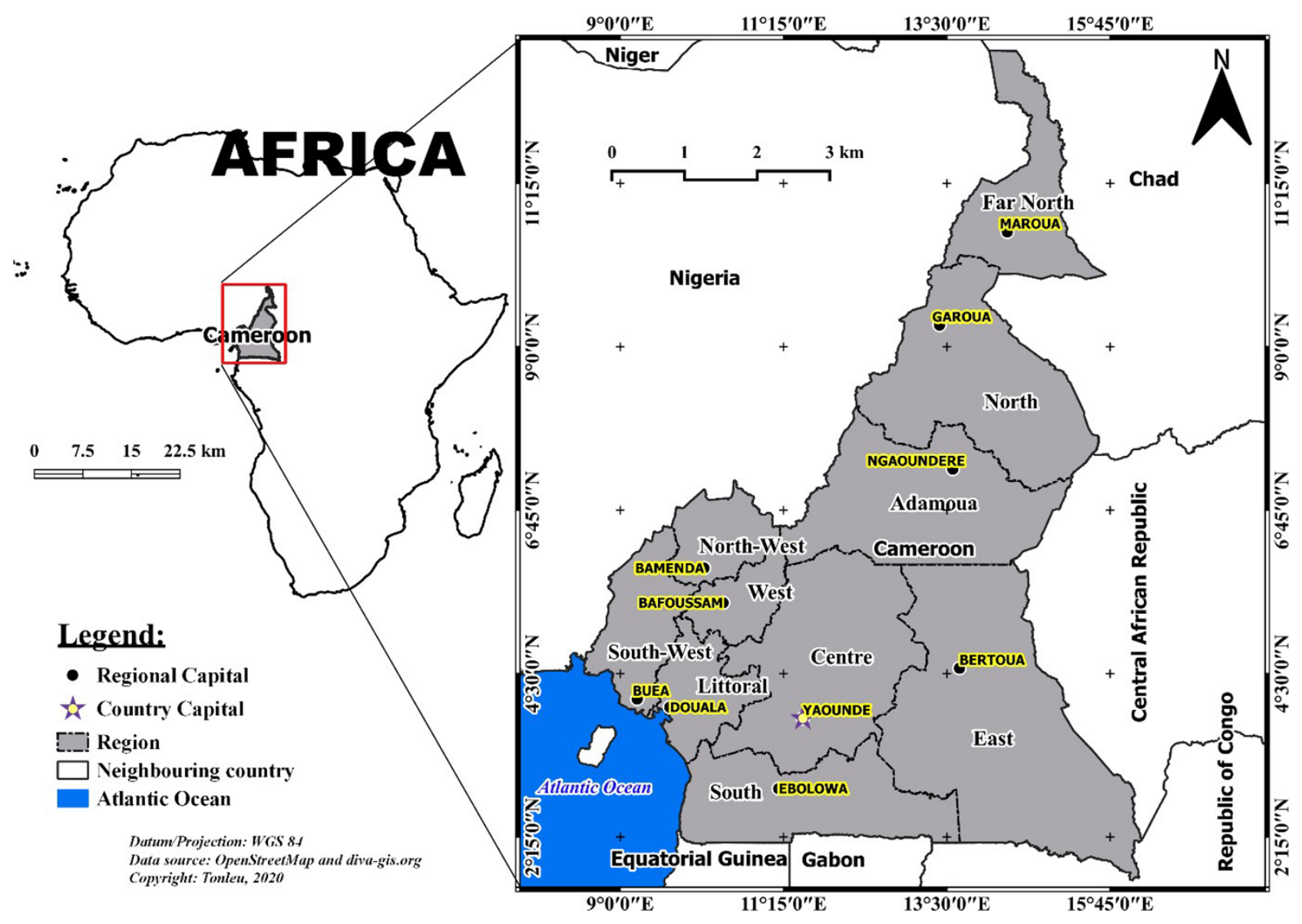

Fig. 1. Map of Cameroon including neighboring countries and borders.

sources of energy as well as highlighting the most recent data on final energy consumption by sector and by source. Furthermore, this paper aims to raise awareness of crucial stakeholders on the present status of energy, RE potential and status of exploitation, RE policy and legal, RE education at school level, and barriers and keys recommendations for the dissemination and development of $\mathrm{RE}$ in Cameroon.

\section{Cameroon's profile}

\subsection{Geographic location of Cameroon}

The world 53rd largest country, Cameroon covers a surface area of $475442 \mathrm{~km}^{2}$ of which $60 \%$ can be used to grow crops [7]. Cameroon is located between $2^{\circ}-13^{\circ}$ North latitude and $8^{\circ}-16^{\circ}$ East longitude. As a consequence, it has a wide range of climatic types: Sudano-Sahelian, Tropical humid, Equatorial monsoon and Guinea equatorial. The SudanoSahelian zone is characterized by nine months of dry season and three months of rainy season. In this zone, higher temperatures, ranging from 35 to $45^{\circ} \mathrm{C}$, are experienced throughout the year [8]. In March, April and May, temperatures can rise over $45^{\circ} \mathrm{C}$, while in December and January temperatures can fall below $10^{\circ} \mathrm{C}$. The Tropical humid zone shows a spread of rainfall over a period of five months on average, while the other months of the year are dry. The Equatorial monsoon zone, which spans from coastal area around the South Region and covers part of the West region, is characterized by heavy annual rainfall. The Guinea equatorial zone is found in the southern part of the country, characterized by a high relative humidity due to continuous rainfall throughout the year and high temperatures.

The country is bordered by Central African Republic (CAR) to the east $(797 \mathrm{~km})$, Chad to the northeast $(1094 \mathrm{~km})$, Nigeria to the west and north $(1690 \mathrm{~km})$, Congo $(523 \mathrm{~km})$, Gabon $(298 \mathrm{~km})$ and Equatorial Guinea $(189 \mathrm{~km})$ to the south. Its coastline spans from the Bight of Biafra to part of the Atlantic Ocean in the Gulf of Guinea $(402 \mathrm{~km})$. Figure 1 illustrates the geographical location of Cameroon, including its borders and neighboring countries.

\subsection{Population and other information}

The population of Cameroon is estimated at about 24.628 million people at the end of year 2018 [9], of which $3.58 \%$ in the Eastern region (East Region), 34,33\% in the Northern regions (Adamaoua, Far North and North regions) and $62.09 \%$ in the Southern regions (Littoral, North West, West, South, and South West regions). The density of population in the country has progressively increased from 


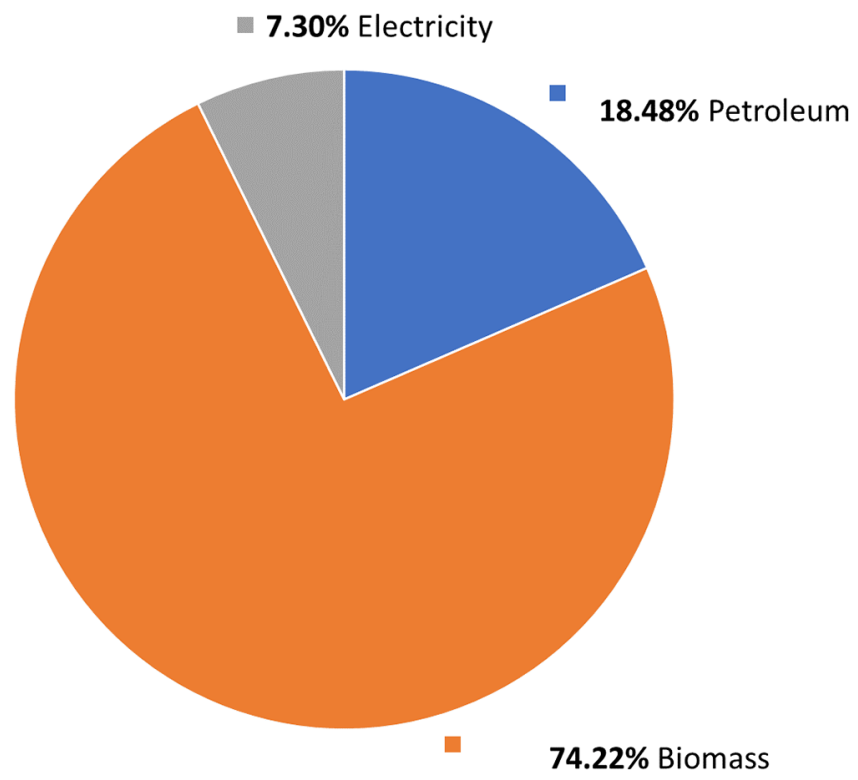

Fig. 2. Total final energy consumption by source.

37.5 person $/ \mathrm{km}^{2}$ in 2005 to 49.9 person $/ \mathrm{km}^{2}$ in 2018 . This density is disproportionately distributed across the country, with 8,52 and 80 person $/ \mathrm{km}^{2}$, respectively in the Eastern, Northern and Southern regions. The Country's electrification rate was around $61.4 \%$ in 2017, with $93.2 \%$ and $21.3 \%$, respectively, of urban and rural population having access to electricity [10]. The electricity consumption level in the country averages $198 \mathrm{kWh}$ per capita per year, while this level is less than $43 \mathrm{kWh} /$ capita/ year in the northern regions (Northern Interconnected Network), around $68 \mathrm{kWh} /$ capita/year in the Eastern Region (East Network) and nearly $291 \mathrm{kWh} /$ capita/year in the Southern regions (South Interconnected Network). Northern and eastern regions have very low levels of energy access (respectively, less than 30\% and 40\%) and other basic services, such as literacy rate, basic sanitation, potable water. In 2018, the gross domestic product of Cameroon was approximately $\$ 38.675$ million, with a growth rate of $4.06 \%$ and a per capita income of $\$ 1534$, with a growth rate of $1.38 \%$ [10].

\section{Energy present status in Cameroon}

\subsection{Energy consumption}

Cameroon's energy consumption shows that biomass, electricity and petroleum are three main sources of energy. Biomass consumption accounts for $74.22 \%$, followed by petroleum (18.48\%) and electricity $(7.30 \%)$, as illustrated by Figure 2. In 2018, the total final energy consumption in the country was 7.41 Mtoe and was dominated by traditional forms of biomass.

The residential sector shares $63.68 \%$ of the total final energy and depends largely on biomass. The Commercial and public services $(14.92 \%)$, transport (13.82\%), industry $(5.15 \%)$ and agriculture / forestry sectors $(0.07 \%)$ rely on petroleum and electricity. Figure 3 illustrates the share of energy consumption by sector.

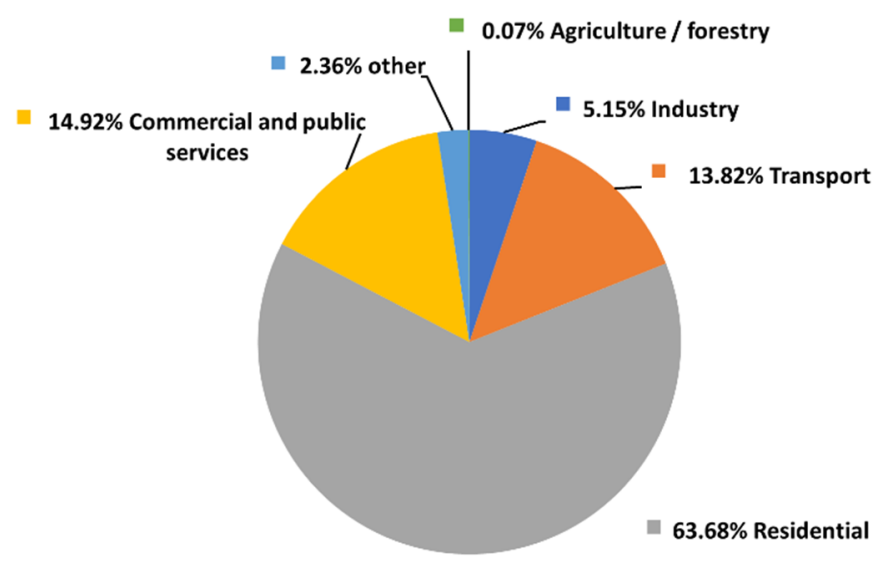

Fig. 3. Total final energy consumption by sector.

\subsection{Electricity generation}

Grid electricity is the leading source of modern energy in the country. Hydropower, natural gas and oil fuels are the major sources of electricity. The country's installed electricity generation capacity at present is approximately 1402 MW, $56.15 \%$ of which is from hydropower, $43.84 \%$ from fossil fuels (17.55\% from natural gas and $26.29 \%$ from oil) and remaining from solar photovoltaic (PV) [11]. Several utility companies are involved in the electricity generation in the country, namely ENEO, GLOBELEQ, ALTAAQA, Sinohydro China and AGGREKO. ENEO, the major electricity operator, has an installed capacity of $1010 \mathrm{MW}, 73.49 \%$ of which from hydropower, $26.49 \%$ from oil fuel and $0.02 \%$ from PV solar. Independent producers, namely, GLOBELEQ (86.08 MW) [12], ALTAAQA $(216.00 \mathrm{MW})$ and AGGREKO (10 MW) generate electricity from oil fuels and natural gas. The current 45 MW of Sinohydro China (hydro memve'ele) installed capacity from hydropower is not yet commissioned.

The national grid is currently composed of three independents networks:

- The North Interconnected Network (NIN) which has produced in 2018 around 365 GWh of electricity to the northern regions of Cameroon;

- The South Interconnected Network (SIN) is the most important of the three networks. With $6023 \mathrm{GWh}$ produced in 2018, representing more than $93 \%$ of the national production, the SIN supplies electricity to the southern regions of Cameroon;

- The East Network (EN), with a total production of 61 GWh, is an autonomous network which supplies electricity solely to the East region of the country.

Currently, there is no transfer of electricity between the three networks. However, there is a future plan, over the period of 2030-2035, for a project to interconnect the three networks through a National Interconnected Network. At present, each network grid has its own transmission network lines, with different voltage levels, 90 and $110 \mathrm{kV}$ for the NIN, $30 \mathrm{kV}$ for the east network and 90 and $225 \mathrm{kV}$ for the SIN. The National Power Transmission Utility (SONATREL), a state-owned transmission company, is in 


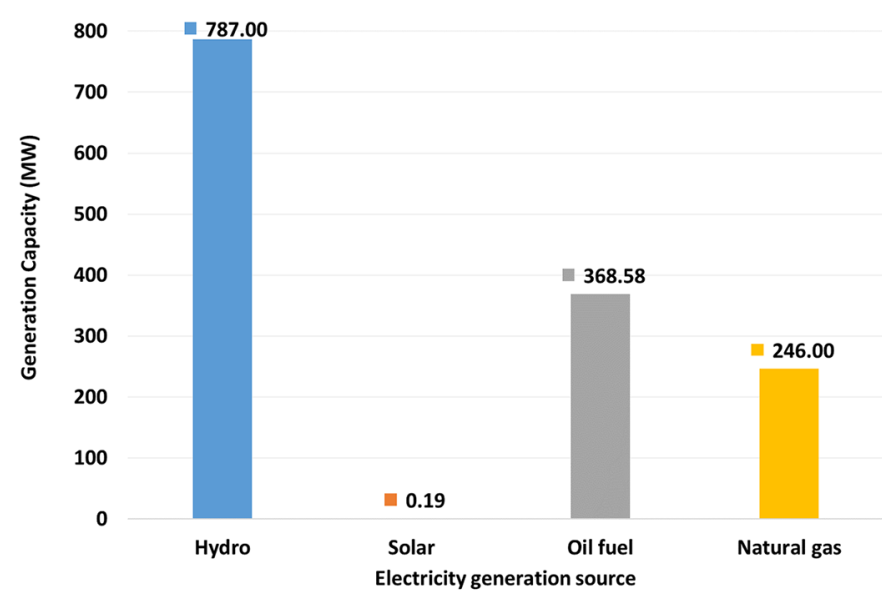

(a)

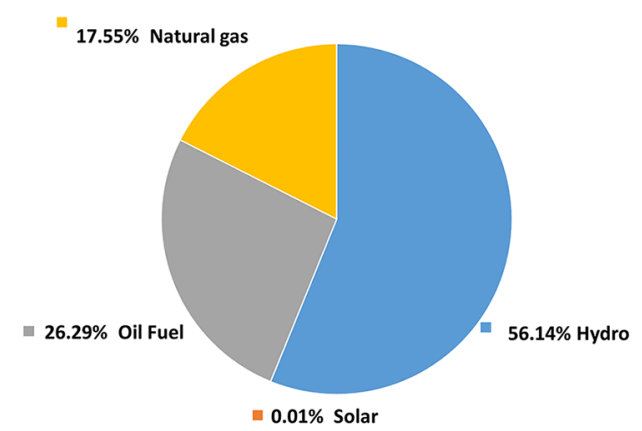

(b)

Fig. 4. (a) Generation capacity by source (b) Share of generation capacity by source.

charge of Cameroon's transmission network. In the context of the future electricity development and the forthcoming National Interconnected Network, it's expected to develop 225 and $400 \mathrm{kV}$ voltage transmission lines, in the context of electricity export in Nigeria, Chad, CAR and Congo, neighboring countries.

In $2018,6977 \mathrm{GWh}$ of electricity was produced in the country, $78.29 \%$ of which from the major electricity operator and the remaining from independent producers [11]. Cameroon's electricity consumption shows that more than three quarter of its total amount is consumed by industry (57.04\%) and residential (20.74\%) sectors. Figure 4a presents the generation capacity by source while Figure $4 \mathrm{~b}$ shows the share of final energy consumption in the country in 2018 .

\section{Status of RE exploitation in Cameroon}

The country is endowed with substantial RE potential, such as biomass, hydro, solar, and wind. However, only a very limited percentage of this RE potential is exploited so far. Currently, RE (except hydro) contributes less than $1 \%$ to the Cameroon's energy mix and the country aims for a $25 \%$ share by 2035 [7]. We present and discuss, at this point, the current status of major renewable energy technologies (RET) for power generation in Cameroon.

\subsection{Hydropower}

Presently, hydropower is the sole RE source on the grid in the country. Hydropower is an attractive source of power for Cameroon with a gross theoretical capability of $294 \mathrm{TWh}$ per year. The technically exploitable capability is around 115 TWh per year, while the economically exploitable capability is approximately $103 \mathrm{TWh}$ per year. This economically exploitable hydro capability is the third largest in Africa, after the Democratic Republic of Congo (419 TWh/yr) and Ethiopia (260 TWh/yr) [13]. There are three large hydropower plants that generate electricity and are located in Edea (286 MW), Song Loulou (384 MW) and Lagdo (72 MW), with the first two located within the River Sanaga Basin. In 2018, hydroelectricity has produced about $5023 \mathrm{GWh}$ in clean electricity representing $71.99 \%$ of the total annual production. This actual level of hydroelectric output corresponds to less than $5 \%$ of the technically exploitable capability potential of Cameroon. The total hydropower capacity under construction is 751 MW, namely: Bini à Warak (75 MW), Lom Pangar (30 MW), Mekin (15 MW), Memve'ele (211 MW) and Nachtigal (420 MW). Several hydropower projects have been announced, with the planned hydro capacity as follows: Downstream Natchigal (350 MW), Kikot (330 MW), Eweng/Ngodi (1150 MW), Song Mbengue (350 MW), the increase in capacity of the existing Song Loulou hydro plant (+150 MW), Song Dong (270 MW) and upstream Edea (200 MW) [14]. Based on the Least-Cost Electricity Sector Development Plan (ESDP) covering the period 2015-2035, the country has set a long-term plan to further develop hydroelectricity. Table 1 provides the number of Most suitable hydropower sites identified per river/basin, gross theoretical and technically exploitable capability. The technical hydropower potential of the country is estimated at around $12.6 \mathrm{GW}$, with approximately $7.3 \mathrm{GW}$ concentrated within the River Sanaga basin. Table 2 provides prioritized hydropower sites by projected network, with projected capacity, for which feasibility studies have been carried out.

\subsection{Solar energy}

Due to its geographic location, Cameroon has moderate to high levels of Global Horizontal Irradiation [15]. Figure 5 maps the photovoltaic power potential in the country. Literature in solar energy studies provides limited information and most recent scientific contributions to the subject are outlined in the following articles. Mas'ud et al. [17] assessed the solar energy readiness in Cameroon by highlighting the irradiation pattern across the country. Abanda [18] underscored that the mean solar irradiance is roughly $5.8 \mathrm{kWh} / \mathrm{m}^{2} /$ day in the northern regions, while it's in the range of $4.0-4.9 \mathrm{kWh} / \mathrm{m}^{2} /$ day in the southern regions of the Country. The lack of reliable network of surface observation stations for collecting weather data has led Ayompe and Duffy [19] to assess the energy output, capacity factor and performance ratio of PV systems using site-specific solar irradiation from long-term satellitederived datasets accessible in Solar GIS software. From the above studies, the solar energy potential available in 
Table 1. Number of hydropower sites and capability per river/basin.

\begin{tabular}{llll}
\hline Basin & Number of sites & $\begin{array}{l}\text { Gross theoretical } \\
\text { capability }(\mathrm{TWh} / \mathrm{yr})\end{array}$ & $\begin{array}{l}\text { Technically exploitable } \\
\text { capability }(\mathrm{TWh} / \mathrm{yr})\end{array}$ \\
\hline Nord & 13 & 25 & 4.1 \\
Sanaga & 34 & 162 & 68 \\
West & 25 & 35 & 11.4 \\
Nyong and Ntem & 13 & 47 & 15 \\
East & 15 & 28 & 6.3 \\
\hline
\end{tabular}

Table 2. Prioritized hydropower sites by network.

\begin{tabular}{|c|c|c|c|c|c|}
\hline Network & Project site & River/Basin & Head (m) & $\begin{array}{l}\text { Planned Installed } \\
\text { capacity (MW) }\end{array}$ & $\begin{array}{l}\text { Investment } \\
\text { costs (Md Fcfa) }\end{array}$ \\
\hline \multirow{15}{*}{ SIN } & Mekin & Dja et Lobo & & 15 & 20.44 \\
\hline & Memve'ele & Ntem & & 211 & 353.98 \\
\hline & Menchum & Catsina & & 84 & 145 \\
\hline & Upstream Nachtigal & Sanaga & 40 & 392 & \\
\hline & Njock phase I & Nyong & & 156 & 169 \\
\hline & Kep & Catsina & & 555.6 & 729 \\
\hline & Rta grand ngodi & Sanaga & 45 & 102 & \\
\hline & Song dong & Sanaga & 24 & 260 & 515 \\
\hline & Njock phase II & Nyong & & 117 & 169 \\
\hline & Upstream Kikot & Sanaga & 25 & 662 & 1,297 \\
\hline & Bayomen & Mbam & & 470 & 925 \\
\hline & Downstream Nachtigal & Sanaga & 30 & 420 & 461 \\
\hline & Mouila mogue & Nyong & & 498 & 980 \\
\hline & $\operatorname{Rta}\left(3^{\text {rd }}\right.$ site $)$ & Sanaga & & 90 & \\
\hline & Upstream Edea & Sanaga & 40 & 474 & 622 \\
\hline \multirow{8}{*}{ NIN } & Bini a warak & Vina nord & 223 & 61.5 & 70 \\
\hline & Mbinjal & Faro & 89 & 83 & 176 \\
\hline & Mandourou & Faro & 115 & 70 & 131 \\
\hline & Upstream Mbam phase I & Mbam & 165 & 74 & 146.5 \\
\hline & Upstream Mbam phase II & Mbam & 165 & 75 & 146.5 \\
\hline & Fo & Faro & 90 & 84 & 249 \\
\hline & Mayo Darle & Mbam & 100 & 16 & 31 \\
\hline & Mayo taram & Mbam & 175 & 29 & 57 \\
\hline \multirow{7}{*}{$\mathrm{EN}$} & Lom pangar phase I & Sanaga & 31 & 15 & \\
\hline & Lom pangar phase II & Sanaga & 31 & 15 & 59 \\
\hline & Colomines & Kadey & 42 & 18 & 35 \\
\hline & Ngoila & Dja & 50 & 124 & 329 \\
\hline & Yenga & Boumba & 60 & 108.5 & 222 \\
\hline & Nki falls & Dja & 108 & 297 & 793 \\
\hline & Zoukomanbale & Kadey & 35 & 29 & 55 \\
\hline
\end{tabular}

the country is massive, despite a poor commitment of the Government of Cameroon (GoC) to boost the solar energy sector. The country is looking forward to implementing a solar PV electrification of some cities under a program named, (Cameroon 2020 Photovoltaic Power Project) PV solar program - Cameroon 2020. Cameroon 2020 Photovoltaic Power Project targets grid-unconnected rural villages as well as grid-connected urban underserved populations. This program is planning to develop 500 MW of installed PV capacity throughout the country 


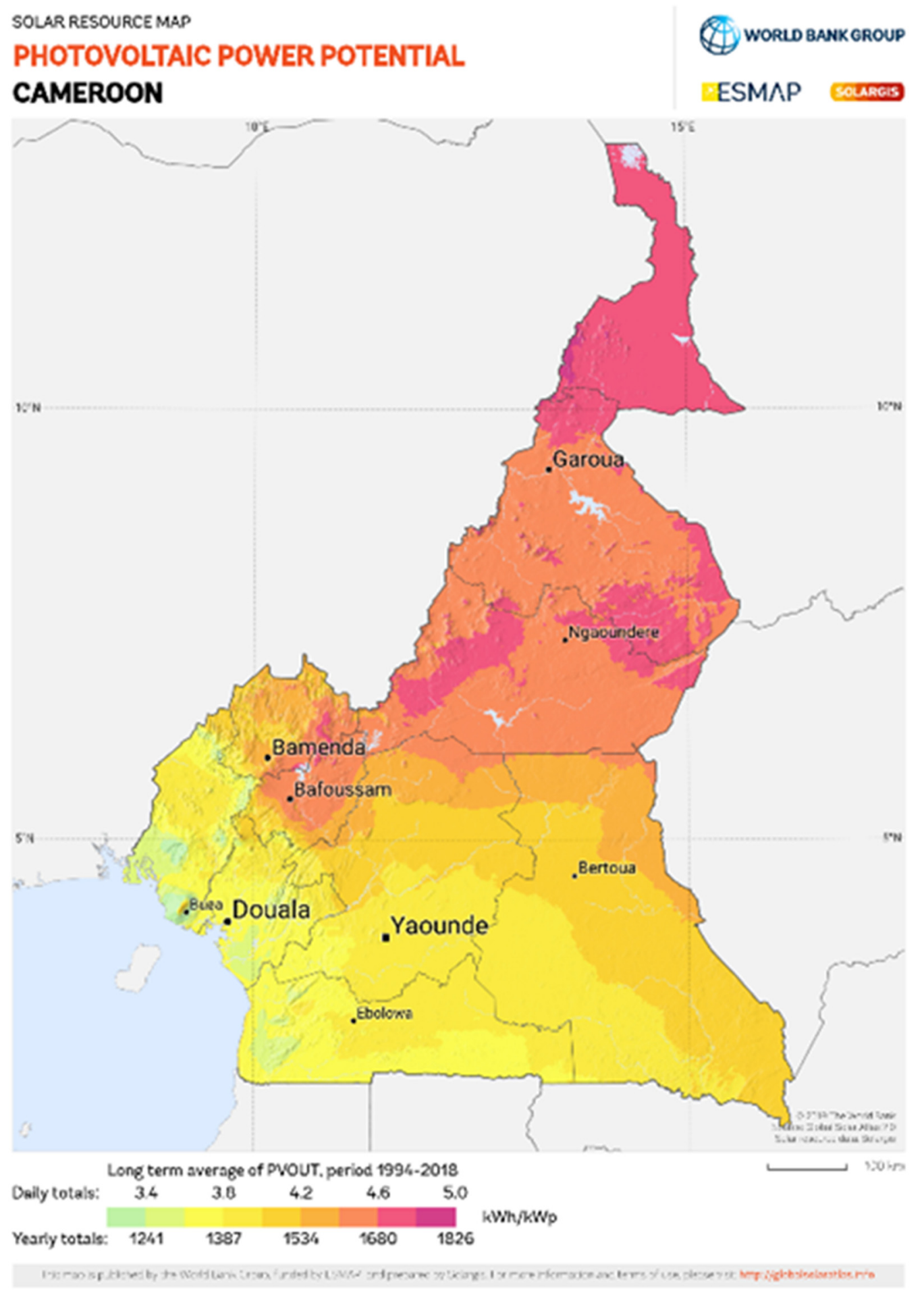

Fig. 5. PV power potential $(\mathrm{kWh} / \mathrm{kWp})[16]$.

for a production of $750 \mathrm{GWh}$ (roughly $1500 \mathrm{MWh} / \mathrm{yr}$ for an installed capacity of $1 \mathrm{MW}$ ). The first phase of this program is scheduled to install a total PV capacity of $110 \mathrm{MW}$ in three considered networks zones (SIN, NIN and EN) of the country, as shown in Table 3. In the SIN zone, Sangmelima and Meyomessala are presently the only two localities, which are enjoying electricity from their solar PV power plants. In the NIN zone, the GoC has appointed Sinohydro, in accordance with the memorandum of understanding between the two parties, to perform feasibility studies for the design, financing, construction, operation and maintenance of a $20 \mathrm{MW}$ solar power plant in Lagdo. 
Table 3. Solar PV sites with projected capacity.

\begin{tabular}{lll}
\hline Network & Site & $\begin{array}{l}\text { Projected capacity } \\
(\mathrm{MW})\end{array}$ \\
\hline \multirow{3}{*}{ SIN } & Sangmelima & 5 \\
& Meyomessala & 2 \\
& Mengon & 1 \\
& Nkilzok & 2 \\
& Yingui & 1 \\
NIN & Ebengbis & 2 \\
EN & Kyeossi & 6 \\
\hline
\end{tabular}

\subsection{Wind energy}

Cameroon is located in a low wind speed region as outlined by kenfack et al. [20] and as a result the country is confronted with several challenges in developing wind energy. Nonetheless, the greatest winds are found in the Far North region, around the Logone \& Chari division and Lake Chad. This high potential is also observed in highlands in the west region. Yet, the wind energy sector is not well-known and the country has no previous experience in wind power generation. Despite rising interest, wind power remains irrelevant in comparison with hydropower which currently contributes at the level of $742 \mathrm{MW}$ to the national electricity production. Nonetheless, the wind energy outlook is looking bright, thanks to the promotion of an investment-friendly strategy to attract investments in the RE sector. Accordingly, a wind power project in the hilly city of Bamboutos (West region) is in the pipeline with public private partnerships (PPP), within the framework of the Cameroonian government's investment programme. When completed, Bamboutos wind farm will be the country's first commercialscale PPP wind project, with an installed capacity of $42 \mathrm{MW}$ that would be extended to $80 \mathrm{MW}$. Once fully operational, the farm will produce approximately $3-6 \%$ of the country's electricity generation. As such, this will introduce wind energy contribution to the national energy consumption and mix. Other than the aforementioned project, the far north region of the country, which has a high-quality potential for harnessing and installing Wind Energy Conversion Systems (WECS), is frequently referred to as the next target of the upcoming investment programme planned by the government in the energy sector. Then again, wind resource has not been sufficiently investigated in the country due to the lack of a reliable and straightforward wind atlas. In scientific literature, very few studies have been achieved so far. Tchinda et al. [21] hypothetically assessed wind energy potential in the far North region of Cameroon. In addition, Tchinda and Kaptouom [22] analyzed wind speeds and energy distributions in the Adamaoua and North regions of Cameroon.
Nfah and Ngundam [23] identified stakeholders for sustainable growths of renewable energy in Cameroon. Abanda [17] investigated potentials, benefits and enabling environment of RE sources in Cameroon. Kidmo et al. [24] performed a statistical analysis of wind speed distribution based on six Weibull Methods for wind power evaluation in the North region. Kidmo et al. [25] assessed wind energy potential for small scale water pumping and concluded that the potential in the North Region of Cameroon is not fitted for generating electricity. Kidmo et al. [26] Assessed once more again wind energy potential at hilltops surrounding the city of Maroua in Cameroon for wind-generated electricity. The study established that wind energy at mountain's ridges, hilltops and highlands could be utilized to improve access to cost-effective low carbon electricity. Other studies $[27,28]$ assessed as well wind energy potential in Ngaoundere and Bamenda. Based on published papers, the vast majority these studies were meant to determine or assess wind power potential, simulate WECS output, using various mathematical models. From the comprehensive literature review performed in the present study, no reference is made to installed WECS in the country.

\subsection{Biomass}

Biomass is a general term that covers biological material derived from living or dead organisms such as plant, trees, wood and agricultural crops and residues, all of which are considered a RE source [29]. Primary biomass resources include woody and herbaceous crops, seeds of oil crops, and residues, while secondary biomass resources, such as sawdust, lops and tops, and animal waste, are processed primary biomass resources. Tertiary biomass resources are post-consumer residues that include animal fats and greases, used vegetable oils, packaging wastes, and construction and demolition debris [30]. As a tropical region, Cameroon is blessed with enormous biomass energy potential evaluated at around 21 million hectares and the country is ranked the 3rd largest biomass potential in subSaharan Africa [31]. This ligneous biomass is mostly utilized as a source of energy for rural households such as traditional uses of biomass for cooking. As mentioned earlier, traditional biomass energy consumption accounts for $74.22 \%$ of primary energy consumption the country.

Relevant studies on biomass resource in Cameroon are summarized below. Mermoz et al. [32] assessed biomass in the Cameroon savanna using ALOS PALSAR data. Based on this biomass assessment, a biomass map over Cameroon, was built. Ackom and Minang [33] assessed the biomass resource potential in Cameroon, mainly, the potential of agricultural and forestry residues. Kamdem et al. [34] studied the potential production of bioethanol, biomethane and wood pellets from lignocellulosic biomass wastes of the banana plant (Musa spp.) in Cameroon.

\subsection{Geothermal energy}

In Cameroon, the presence of more than hundreds of thermal springs in the corridor of the active Cameroon Volcanic Line, as well as repeated eruptions of Mount Cameroon, are supportive of geothermal development in 
the country [35]. Geothermal energy has not been harnessed to date in Cameroon and there is no known energy supply derived from geothermal source. The geothermal energy potential, which has not been completely assessed, is up to now unknown. In the literature, there exists rather very few studies regarding the subject. Keutchafo et al. [35] reviewed issues of geothermal exploration with a focus on existing barriers hindering the geothermal energy development in Cameroon. By appraising geothermal resources and use in Cameroon, Kana et al. [36] identified several potential geothermal sites using thermal methods. In that study, the highlight of direct and indirect use of geothermal energy in Cameroon was performed to help raise stakeholders' awareness.

\subsection{Wave and tidal energy}

Potentials for wave and tidal energy in Cameroon are concentrated on coastal areas in littoral, South West and South regions. Very few scholars have discussed wave and tidal power in the country. A decade ago, the GoC has hired MRS Power Cameroon, a subsidiary of MRS Holding Ltd to realize feasibility studies on potentials for wave and tidal power in the country [17]. The outcome of these feasibility studies is still awaited and at present, there is no known plan to harness these potentials sources of energy. Furthermore, potentials for tidal current and wave energy are up to now unknown.

\section{RE policy and legal}

Historically, to boost the development of RE, the country has relied on reforms on the electricity sector, led by hydroelectricity largely developed compared to other RE sources such as wind, solar and biomass. Initially, the law $\mathrm{n}^{\circ} 98 / 022$ of 24 December 1998 governing the electricity sector, which is a general legislation concerning the electricity sector, focused on hydroelectricity development only. Afterwards, the electricity Law 2011/022, governing the electricity sector and promulgated on December 14, 2011, clearly defined RE sources [37]. Key changes under this new legislation included the role of the State in:

- ensuring the promotion and development of RE;

- establishing the opportunity for the transmission system operator or any local distributor to purchase the surplus of electricity generated from RE sources;

- fixing tax benefits for products, goods and services intended for RE exploitation;

- Creating an agency responsible for the promotion and development of RE.

This law precisely shapes the legal and institutional supervision for RE promotion, by creating the Department of Renewable energy within the Ministry of Energy and Water Resources.

To cope with the growth of electricity demand, several government plans and programs for energy development have been announced and deliverables are highly expected. The Master Plan for the Development of RE in Cameroon is still to be released. The rural electrification master plan, which focuses as well on RE such as solar energy in the northern regions and hydro energy in the southern regions, is as well to be released.The ESDP up to 2035 is the latest government plan aimed at helping define, for various scenarios of the demand forecasting, using the significant identified hydroelectric sites of the country, optimal sequences of facilities that are the least cost solutions to cope with the demand, or to improve the reliability of the electrical system. Under the ESDP - 2035, short, medium and long terms scenarios are studied and examined, and the forecast of demand includes national needs in addition to electricity exportation to neighboring CAR, Chad, and Nigeria.The country has set ambitious RE targets, under an optimistic long-term scenario, such as achieving more than $5500 \mathrm{MW}$ of hydropower installed capacity by 2035 [7]. In terms of exportations, the optimistic long-term scenario forecasts a demand of an interconnection with Nigeria estimated at $500 \mathrm{MW}$ from 2031 to 2035 and with Chad estimated at $150 \mathrm{MW}$ in 2035.

The existing main Government bodies involved in the promotion and the follow-up of the use of RE, include:

- The Ministry of Energy and Water Resources (MINEE), in charge of implementing government action in the RE sector, overseeing energy sector activities, formulating policy, laws, and directives for the promotion of RE;

- The Ministry of Economy, Planning, and Regional Development works with MINEE to promote investments in the electricity sector;

- The Ministry of Finance provides financial support and different incentives, such as Value Added Tax (VAT) exemptions, to boost the renewable energy sector;

- The Ministry of Scientific Research and Innovation is responsible for conducting research in the energy and hydrological fields and, in conjunction with MINEE, is responsible for promoting new energy;

- The Ministry of Environment, Protection of Nature and Sustainable Development is in charge of the promotion of sustainable development in the renewable energy sector; - The Rural Electrification Agency is a legal public entity with financial autonomy, focused on promoting and implementing rural electrification in Cameroon and managing the Rural Energy Fund;

- The Electricity Sector Regulatory Agency is responsible for policy and regulatory framework and possible funding, regulating the electricity sector as well as setting electricity rates and determining electrical standards. The agency is also in charge of the promotion and the follow-up of the use of the primary sources of energy, in particular renewable;

- Electricity Development Corporation (EDC) is a stateowned company that develops the electricity sector, including all hydroelectric projects in the country;

- ENEO Cameroun is the main utility company responsible for the distribution of electricity;

- SONATREL is the national power transmission utility company, a public administrator and operator of Cameroon's transmission network, a state-owned agency, with the GoC as the sole shareholder.

- Independent power producers (IPPs) are private distribution companies. 


\section{RE job training}

In 1957, the country has put into service, its first plant, Edea I. Since then, more hydropower plants, namely Edea II (1958), Edea III (1975), Lagdo (1983), Song Loulou (1991) were put into production, and more hydropower projects are on their way nowadays. The country's manpower is hired from electrical, mechanical and civil engineering background and trained in hydroelectricity. The national advanced school of engineering of the University of Yaoundé I (ENSPY), up to now, is training formally in electrical, mechanical and civil engineering. Specific hydroelectricity training is provided to engineers through on-the-job training and short courses at the expense of the national utility company. With the expansion of RET to other sources of energy, such as solar, wind, biomass, more training capability is needed to train manpower and build capacity in RE fields. There are very few academic institutions and scientific research centers dedicated to RE and all of them are state-owned. The department of $\mathrm{RE}$ at the national advanced school of engineering in Maroua, offers bachelor degrees courses in six semesters and master degrees courses in four semesters, in the fields of biomass, solar and wind. The national advanced school of public works (ENSTP) Yaoundé, offers master degrees courses in four semesters, in different fields of RE. The national laboratory for energetics research a subsidiary branch of the geologic and mining research institute, is devoted RE research.

\section{Barriers to RE development}

$\mathrm{RE}$ is currently the leading source of energy in Cameroon for electricity generation and residential sector (traditional uses of biomass for cooking). If properly harnessed, RE could meet an important share of energy demand from commercial and public services, transport, industrial and agricultural sectors. Despite the potential of $\mathrm{RE}$ in satisfying energy needs of the country, the success of RE has been hindered by a combination of three main factors, namely, policy and legal, technical and financial issues. The country does not have a precise policy and legal framework for the development and promotion of RE, despite heavy investment trends in Cameroon's hydropower sub-sector. There is limited trained manpower in addition to lack of expertise in RET for the successful dissemination of RE. Major financial issues for the successful implementation of $\mathrm{RE}$ projects include the absence of low-cost, long-term financing mechanisms, the lack of stakeholders' awarenessin RE financing mechanisms in addition to unaffordable costs of RET to the poor population.

\section{Key recommendations on RE development}

For the successful development of RE in the country, the GoC, through the Ministry of Energy and Water Resources (MINEE), in charge of implementing government action in the RE sector, needs to formulate proactive and long-term policy, laws, and directives for the promotion of RE. Then, through its agencies and funding bodies, the GoC needs to build training and research networks in $\mathrm{RE}$ and equip researchers so to emulate capacity-building initiatives and collaborative research for the rapid dissemination of RET across the country. Furthermore, there is a need to empower stakeholders (scholars, policymakers and entrepreneurs) with the necessary knowledge and skills to disseminate, develop and adapt RE systems to local contexts. Finally, the GoC needs to extend financial support in favor of the dissemination and development of $\mathrm{RE}$ through a scheme of incentives, from governmentguaranteed purchase prices for RE electricity to competitive mechanisms.

\section{Conclusion}

Based on the study, Cameroon has huge RE resources that can be harnessed to generate pollution-free power. The following facts can be summarized regarding RE situation in the country. Biomass, electricity and petroleum are three main sources of energy. In 2018, the total final energy consumption in the country was 7.41 Mtoe, $74.22 \%$ of which was from biomass, $18.48 \%$ from fossil fuels and $7.30 \%$ from electricity. The country's installed electricity generation capacity at present is $1402 \mathrm{MW}, 56.15 \%$ of which is from hydropower, $43.84 \%$ from fossil fuels $(17.55 \%$ from natural gas and $26.29 \%$ from oil) and $0.01 \%$ from solar PV. In 2018, 6977 GWh of electricity was produced in the country, $78.29 \%$ of which from the major electricity operator (ENEO S.A. Cameroon) and $21.71 \%$ from independent producers (GLOBELEQ, ALTAAQA Sinohydro China and AGGREKO). Furthermore, more than three quarters of electricity produced were consumed by industry $(57.04 \%)$ and residential (20.74\%) sectors. Moreover, hydroelectricity, has produced about 5023 GWh in clean electricity representing $71.99 \%$ of the total annual production. Mean solar irradiance is approximately $5.8 \mathrm{kWh} / \mathrm{m}^{2} /$ day in the northern regions, while it averages $4.5 \mathrm{kWh} / \mathrm{m}^{2} /$ day in the southern regions of the Country. Solar power plants programs, which currently target gridunconnected rural villages, are scheduled for a total installed PV capacity of $110 \mathrm{MW}$. The greatest winds in Cameroon are found in the Far North region and in highlands in the west region of the Country, but wind power generation is non-existent. Geothermal,tidal current and wave energy potentials are up to now unknown. There is a general legislation in the country concerning the electricity sector, focused mainly on hydroelectricity development. The country is currently building its RE education, research and scholars' capacity.

Acknowledgments. The authors would like to thank the anonymous contributors for their various aids. The authors also express their gratitude to the many colleagues and organizations that openly shared data in this project.

\section{References}

1. BP Statistical Review, BP Statistical Review, 2019. https:// www.bp.com/en/global/corporate/energy-economics/ statistical-review-of-world-energy.html [accessed 12.12.20] 
2. P.K. Halder, N. Paul, M.U.H. Joardder, M. Sarker, Energy scarcity and potential of renewable energy in Bangladesh, Renew. Sustain. Energy Rev. 51, 1636-1649 (2015)

3. Gwec and Greenpeace, Global Wind Energy Outlook, 2014. www.gwec.net. [accessed 12.12.20]

4. EUROBSERV'ER, the state of renewable energies in Europe, 2013 edition. https://www.ourenergypolicy.org/ wp-content/uploads/2014/03/EurObservER.pdf [accessed 12.12.20]

5. E. Ersoy, M.E. Schaffer, J. Ditzen, BP Statistical Review of World Energy 2019. (68 ed.) British Petroleum. https:// www.bp.com/content/dam/bp/business-sites/en/global/ corporate/pdfs/energy-economics/statistical-review/bp-statsreview-2019-full-report.pdf. [accessed 15.12.20]

6. Y.S. Mohammed, M.W. Mustafa, N. Bashir, Status of renewable energy consumption and developmental challenges in Sub-Sahara Africa, Renew. Sustain. Energy Rev. 27, 453-463 (2013)

7. Power Africa Off-grid Project (USAID), Off-Grid Solar Market Assessment Cameroon, 2019. https://www.usaid. gov/sites/default/files/documents/1860/PAOP-CameroonMarketAssessment-Final-Digital_508.pdf [accessed 12.12.20]

8. D.K. Kidmo et al., Wind Energy for Electricity Generation in the Far North Region of Cameroon, Energy Procedia 93, 66-73 (2016)

9. National Institute of Statistics (Cameroon), Statistical Year Book of Cameroon 2018. http://ghdx.healthdata.org/orga nizations/national-institute-statistics-cameroon [accessed 13.12.20]

10. World Development Indicators 2020. https://data.world bank.org/country/cameroon [accessed 02.12.20]

11. A. Report, 2018 Annual Report - ENEO CAMEROON S.A, 2018. https://eneocameroon.cm/images/pdf/Eneo-2018-An nual-Report.pdf [accessed 10.12.20]

12. Globeleq, 2015. https://www.globeleq.com/media/\#pr_wrap per [accessed 15.12.20]

13. World Energy Council, 2004 Survey of energy resources, 20th Ed. (Elsevier Ltd, 2004)

14. MINEE, Projet de développement du secteur de l'energie (pdsen) volume 3 - etude de l'offre en moyens de production, 2014

15. E. Muh, F. Tabet, Sustainable energy policies in Cameroon: a holistic overview, Renew. Sustain. Energy Rev. 82, 0-10 (2017)

16. S. resource data: S. (C) 2019 The World Bank, Source: Global Solar Atlas 2.0, Solar maps of Cameroon

17. A.A. Mas'ud, A. Vernyuy Wirba, F. Muhammad-Sukki, I.A. Mas'ud, A.B. Munir, N. Md Yunus, An assessment of renewable energy readiness in Africa: case study of Nigeria and Cameroon, Renew. Sustain. Energy Rev. 51, 775-784 (2015)

18. F.H. Abanda, Renewable energy sources in Cameroon: potentials, benefits and enabling environment, Renew. Sustain. Energy Rev. 16, 4557-4562 (2012)

19. L.M. Ayompe, A. Duffy, An assessment of the energy generation potential of photovoltaic systems in Cameroon using satellite-derived solar radiation datasets, Sustain. Energy Technol. Assess., 2013. DOI: 10.1016/j.seta.2013.10.002.

20. J. Kenfack, J. Voufo, P.S. Ngohe Ekam, J.K. Lewetchou, U. Nzotcha, Overcoming local constraints when developing renewable energy systems for the electrification of remote areas in Africa, Renew. Energy Environ. Sustain. 5, 1-10 (2020)

21. R. Tchinda, J. Kendjio, E. Kaptouom, D. Njomo, Estimation of mean wind energy available in far north Cameroon, Energy Convers. Manag. 41, 1917-1929 (2000)

22. R. Tchinda, E. Kaptouom, Wind energy in Adamaoua and North Cameroon provinces, Energy Convers. Manag. 44, 845-857 (2003)

23. E.M. Nfah, J.M. Ngundam, Identification of stakeholders for sustainable renewable energy applications in Cameroon, Renew. Sustain. Energy Rev. 16, 4661-4666 (2012)

24. D.K. Kidmo, R. Danwe, Y.S. Doka, N. Djongyang, Statistical analysis of wind speed distribution based on six Weibull Methods for wind power evaluation in Garoua, Cameroon, J. Renew. Energies 18, 105-125 (2015)

25. D.K. Kidmo, N. Djongyang, S.Y. Doka, D. Raidandi, Assessment of wind energy potential for small scale water pumping systems in the north region of Cameroon, Int. J. Basic Appl. Sci. 3, 38-46 (2013)

26. D.K. Kidmo et al., Assessment of wind energy potential and cost estimation of wind-generated electricity at hilltops surrounding the city of Maroua in Cameroon, in: AIP Conference Proceedings, 2016, vol. 1758, doi: 10.1063/ 1.4959388.

27. M.Y. Kazet, R. Mouangue, A. Kuitche, J.M. Ndjaka, Wind energy resource assessment in Ngaoundere locality, Energy Procedia 93, 74-81 (2016)

28. D. Afungchui, C.E. Aban, Analysis of wind regimes for energy estimation in Bamenda, of the North West Region of Cameroon, based on the Weibull distribution, J. Renew. Energies 17, 137-147 (2014)

29. S. Dasappa, Potential of biomass energy for electricity generation in sub-Saharan Africa, Energy Sustain. Dev. 15, 203-213 (2011)

30. A. Faaij, Modern biomass conversion technologies, vol. 11. Springer, (2006)

31. Y.D. Fondja Wandji, Energy consumption and economic growth: evidence from Cameroon, Energy Policy 61, 1295-1304 (2013)

32. S. Mermoz, T. Le Toan, M. Réjou-Méchain, Biomass assessment in the Cameroon savanna using ALOS PALSAR data, Remote Sens. Environ., 2014. DOI: 10.1016/j. rse.2014.01.029

33. E. Ackom, P.A. Minang, Modern bioenergy from agricultural and forestry residues in Cameroon: potential, challenges and the way forward, Energy Policy 63, 101-113 (2013)

34. I. Kamdem, K. Tomekpe, P. Thonart, Potential production of bioethanol, biomethane and wood pellets from lignocellulosic biomass wastes of the banana plant (Musa spp.) in Cameroon, Biotechnol. Agron. Soc. Environ. 15, 471-483 (2011) 
35. N.-A.K. Keutchafo, P. Noel, N. Nkouamen, J.-P. Tchouankoue, Barriers of Geothermal Exploration in Cameroon, In: Proceedings of 7th African Rift Geothermal Conference Kigali, Rwanda, 31st October - 2nd November 2018. https://www.researchgate.net/publication/332819773
36. J. Kana, N. Djongyang, R. Danwe, B. Ramadhan, Appraisal of geothermal resources and use in Cameroon, African J. Sci. Technol. Innov. Dev. 9, 1-7 (2017)

37. National Assembly, Law governing the electricity sector in cameroon, Yaoundé, 2011

Cite this article as: Dieudonné Kaoga Kidmo, Kodji Deli, Bachirou Bogno, Status of renewable energy in Cameroon, Renew. Energy Environ. Sustain. 6, 2 (2021) 